\title{
Correlation between arterial blood gas analysis and outcome in patients with severe head trauma
}

\author{
Amirmohammad Bazzazi, M.D., ${ }^{1}$ Mohammad Amin Valizade Hasanloei, M.D., ${ }^{2}$ \\ Alireza Mahoori, M.D., ${ }^{2}$ Mahdia Gholamnejad, M.D., ${ }^{3}$ Habibeh Tarverdipour, M.D. ${ }^{4}$
}

\begin{abstract}
${ }^{1}$ Department of Neurosurgery, Urmia University of Medical Sciences, Urmia, Iran; ${ }^{2}$ Department of Anesthesiology,urmia University of Medical Sciences, Urmia, Iran; ${ }^{3}$ Department of Pulmonary Medicine, Urmia University of Medical Sciences, Urmia, Iran; ${ }^{4}$ Urmia University of Medical Sciences, Urmia, Iran
\end{abstract}

\begin{abstract}
BACKGROUND: Traumatic brain injury is one of the major concerns of global public health, because it is the main cause of morbidity and mortality between young people. This study aimed to investigate the possible association between the parameters of arterial blood gas (ABG) and outcome of patients with severe head trauma.

METHODS: In this prospective study, 70 patients with severe head trauma were studied in Urmia Imam Khomeini hospital during 18-month period of time. The parameters of ABG were documented within the Ist hour of admission, and their correlation was evaluated with Glasgow coma scale (GCS) and Glasgow outcome score (GOS). These parameters also were compared between expired and discharged patients.

RESULTS: Seventy patients with severe head trauma including 60 males (85.7\%) and 10 females (14.3\%) with a mean age of $34.34 \pm$ I 4.82 (range: 18-76) years were studied. The mortality rate during hospitalization was $38.6 \%$ ( $n=27$ ). There was no significant correlation between the parameters of $A B G$ and GCS score and GOS scores. Furthermore, there was no significant difference between the survivors and non-survivors in terms of the mean value of $A B G$ parameters $(p>0.05)$.
\end{abstract}

CONCLUSION: ABG at the time of admission is not a significant predictor of outcome in patients with severe head trauma.

Key words: Arterial blood gas; outcome; severe head trauma.

\section{INTRODUCTION}

Traumatic brain injury is a major problem all over the world, because it is the main cause of death in the young population. Since traffic accidents constitute the most frequent underlying etiology of head trauma, the incidence of traumatic brain injury is expected to increase. It is anticipated that traumatic brain injury would be the leading cause of death and disability in $2020 .^{[1,2]}$ The primary injury is due to direct mechanical

\footnotetext{
Address for correspondence: Mohammad Amin Valizade Hasanloei, M.D. Ershad Ave. Emam Hospital, Urmia, Iran

Tel: 984413457286

E-mail: aminvalizade@yahoo.com

Qucik Response Code Ulus Travma Acil Cerrahi Derg

damage and the secondary damage (delayed non-mechanical) is induced by changes in cerebral blood flow (such as hypoand hyper-perfusion), inadequate cerebral oxygenation, and impairment of cerebrovascular auto-regulation, cerebral metabolic dysfunction, excitotoxic cell damage, and inflammation. While the primary damage could not be therapeutically influenced, treatment should be focused on the secondary damage. ${ }^{[3,4]}$ The identification of reliable predictors of outcome after head injury is essential to appropriate counseling of family members and employing resources. Some authors believe that arterial $\mathrm{PCO}_{2}$ at the time of admission is a significant prognostic factor in patients with traumatic head injury, ${ }^{[5]}$ whereas others have denied the parameters of arterial blood gas $(A B G)$ as reliable indicators of short term outcome in these patients. ${ }^{[6]}$ The present prospective study aimed to investigate a possible association between the parameters of $A B G$ and outcome in patients with severe head injury.

\section{MATERIALS AND METHODS}

After being approved by the Ethics Committee of Urmia Uni- 
versity of Medical Sciences, this prospective cross-sectional study was performed in intensive care unit and emergency department of Urmia Imam Khomeini Teaching Hospital during 18 months period of time (January 2012 to July 2013). Written informed consents were obtained from patients' accompanying family members/guardian prior to enrollment. Patients younger than 18 and older than 80 years, with severe trauma to the thoracic/abdominal regions, requiring operation on the brain, thoracic region, or abdomen, hospital stay $<24$ hours, and with chronic obstructive pulmonary disease were excluded from the study. Finally, 70 patients with severe head trauma Glasgow coma scale (GCS $\leq 8$ ) were included in the study.

All the patients were thoroughly examined by an experienced neurosurgeon at the time of admission and regularly during the hospital stay and were managed similarly during hospitalization.

Severity of head trauma was accessed by GCS score on admission, 24 hours, 48 hours, and I week later, and at discharge. Glasgow outcome score (GOS) was also calculated in the discharged cases.

The parameters of ABG including acidity $(\mathrm{pH}), \mathrm{O}_{2}$ and $\mathrm{CO}_{2}$ pressure $\left(\mathrm{PO}_{2}\right.$ and $\mathrm{PCO}_{2}$, respectively), bicarbonate $\left(\mathrm{HCO}_{3}\right)$, and $\mathrm{O}_{2}$ saturation $\left(\mathrm{O}_{2} \mathrm{Sat}\right)$ were determined within 4 hours of admission.

\section{Statistical Analysis}

Data were expressed as mean \pm standard deviation and were analyzed by independent t-test and Pearson's correlation coefficient ( $r$ ) among two groups using SPSS statistical software

Table I. Final diagnoses in the studied patients with severe head trauma

\begin{tabular}{lcc}
\hline Diagnosis & $\mathbf{n}$ & $\%$ \\
\hline Diffuse axonal injury & 30 & 42.9 \\
Subdural hemorrhage & 13 & 18.6 \\
Contusion & 7 & 10 \\
Subdural hemorrhage + contusion & 4 & 5.7 \\
EDH & 3 & 4.3 \\
Subarachnoid hemorrhage + contusion & 2 & 2.9 \\
IVH + contusion & 2 & 2.9 \\
IVH & 2 & 2.9 \\
Subdural hemorrhage + ICH & 2 & 2.9 \\
Subarachnoid hemorrhage & $\mathrm{I}$ & 1.4 \\
IVH + Subarachnoid hemorrhage + contusion & $\mathrm{I}$ & 1.4 \\
EDH + Subarachnoid hemorrhage + contusion & $\mathrm{I}$ & 1.4 \\
EDH + contusion & $\mathrm{I}$ & 1.4 \\
Subdural hemorrhage + SAH & $\mathrm{I}$ & 1.4 \\
\hline
\end{tabular}

EDH: Epidural hemorrhage; ICH: Intracerebral hemorrhage; IVH: Intraventricular hemorrhage. version 16 (Chicago, IL, USA). $\mathrm{p}<0.05$ was considered as statistically significant.

\section{RESULTS}

Seventy patients with severe head trauma, including 60 males (85.7\%) and 10 females (14.3\%) with a mean age of $34.34 \pm \mid 4.82$ (range: 18-76) years were included in the study. The mechanism of trauma was a traffic accident in 59 cases (84.3\%), falling in eight cases (11.4\%), and physical assault in three cases (4.3\%). Final diagnoses in the studied group of patients are summarized in Table $\mathrm{I}$.

Laboratory findings, ABG, GCS, and GOS at the time of admission and during hospitalization are summarized in Table 2. The duration of hospital stay was $17.31 \pm 16.26$ days. Fortythree patients (6I.4\%) were discharged from the hospital and 27 patients (38.6\%) expired.

Table 2. Laboratory findings, $A B G, G C S$, and $G O S$ in the patients with severe head trauma at the time of admission and during hospital stay

\begin{tabular}{cc}
\hline Variable & $\begin{array}{c}\text { Meantstandard } \\
\text { deviation (range) }\end{array}$ \\
\hline
\end{tabular}

\begin{tabular}{|c|c|}
\hline \multicolumn{2}{|l|}{ Serum parameters (admission) } \\
\hline Glucose (mg/dL) & $186.15 \pm 70.25(94-376)$ \\
\hline Blood urea nitrogen $(\mathrm{mg} / \mathrm{dL})$ & $35.17 \pm 14.56(20-120)$ \\
\hline Potassium (mEq/dL) & $4.46 \pm 3.66(0.8-6.3)$ \\
\hline Sodium $(\mathrm{mEq} / \mathrm{dL})$ & $143.97 \pm 4.79(135-170)$ \\
\hline Hemoglobin (mg/dL) & $12.55 \pm 2.5 \mid(7.5-19.2)$ \\
\hline Creatinine (mg/dL) & $1.00 \pm 0.29(1-2)$ \\
\hline Prothrombin time (seconds) & $14.31 \pm 2.12(13-24)$ \\
\hline $\begin{array}{l}\text { Partial thromboplastin } \\
\text { time (seconds) }\end{array}$ & $34.36 \pm 13.68(23-130)$ \\
\hline International normalized ratio & $1.30 \pm 0.45(1-3)$ \\
\hline \multicolumn{2}{|l|}{ Arterial blood gas (admission) } \\
\hline $\mathrm{pH}$ & $7.26 \pm 0.59$ \\
\hline $\mathrm{PCO}_{2}(\mathrm{mmHg})$ & $34.63 \pm 8.43$ \\
\hline $\mathrm{HCO}_{3}(\mathrm{mEq} / \mathrm{L})$ & $|8.7| \pm 4.29$ \\
\hline $\mathrm{PO}_{2}(\mathrm{mmHg})$ & II $8.98 \pm 54.79$ \\
\hline $\mathrm{O}_{2} \mathrm{Sat}(\%)$ & $94.63 \pm 6.78$ \\
\hline \multicolumn{2}{|l|}{ Glasgow coma scale score } \\
\hline At admission & $6.27 \pm 1.55(3-8)$ \\
\hline 24 hours & $6.52 \pm 1.75(3-11)$ \\
\hline 48 hours & $6.75 \pm 2.33(3-14)$ \\
\hline I week & $8.50 \pm 3.10(3-15)$ \\
\hline At discharge & $8.7 I \pm 5.23(3-15)$ \\
\hline Glasgow outcome scale & $2.70 \pm 1.64(1-5)$ \\
\hline
\end{tabular}

GCS: Glasgow coma scale; ABG: Arterial blood gas; GOS: Glasgow outcome score. 
Correlation between the parameters of $A B G$ at the time of admission with GCS score and GOS are summarized in Table 3. Accordingly, there was no significant correlation between the mentioned parameters.

Mean parameters of $A B G$ are compared between the expired and discharged patients as shown in Table 4. According to this table, there was no significant difference between the two groups in terms of ABG parameters $(p>0.05)$.

\section{DISCUSSION}

Traumatic brain injury is the leading cause of death and longtime disability in the young ( $<40$ years) individuals all over the world. In severe trauma, the mortality rate can reach up to $50 \%$. This rate has fallen from $80 \%$ in 1950 to $20 \%$ over recent years. The mortality rate in the present work was $38.6 \%$, which seems to be average of the reported value by various articles. ${ }^{[7]}$

Since the management and used medications in our patients are similar to those in more developed countries, higher rate of mortality seems to be due to more severe injuries, possibly because of lower traffic standards and unsafe vehicles. Thus, the most useful way to diminish traumatic head injuries and their consequences is the prevention. ${ }^{[I]}$

The mean age of our patients was 34.34 14.82 (range: 18-76) years and the males were included the $(85.7 \%)$ of patients.

Table 3. Correlation between the parameters of ABG at the time of admission with GCS score (at different intervals) and GOS

\begin{tabular}{|c|c|c|c|c|c|}
\hline \multirow[t]{2}{*}{ Parameters } & \multicolumn{4}{|c|}{ GCS } & \multirow[t]{2}{*}{ GOS } \\
\hline & 24 hour & 48 hour & I week & Discharge & \\
\hline \multicolumn{6}{|l|}{$\mathrm{pH}$} \\
\hline$r$ & 0.01 & 0.03 & 0.04 & -0.04 & 0.01 \\
\hline $\mathrm{P}$ & 0.93 & 0.80 & 0.75 & 0.71 & 0.92 \\
\hline \multicolumn{6}{|l|}{$\mathrm{PCO}_{2}$} \\
\hline$r$ & -0.09 & -0.11 & 0.15 & -0.03 & -0.03 \\
\hline $\mathrm{P}$ & 0.43 & 0.32 & 0.26 & 0.80 & 0.75 \\
\hline \multicolumn{6}{|l|}{$\mathrm{HCO}_{3}$} \\
\hline$r$ & 0.14 & 0.13 & 0.22 & 0.16 & 0.16 \\
\hline $\mathrm{P}$ & 0.24 & 0.25 & 0.09 & 0.18 & 0.17 \\
\hline \multicolumn{6}{|l|}{$\mathrm{PO}_{2}$} \\
\hline$r$ & -0.05 & -0.02 & 0.06 & 0.15 & 0.15 \\
\hline $\mathrm{P}$ & 0.96 & 0.88 & 0.64 & 0.21 & 0.20 \\
\hline \multicolumn{6}{|l|}{$\mathrm{O}_{2} \mathrm{Sat}$} \\
\hline$r$ & -0.09 & 0.01 & 0.12 & 0.17 & 0.16 \\
\hline $\mathrm{P}$ & 0.45 & 0.95 & 0.38 & 0.14 & 0.17 \\
\hline
\end{tabular}

GCS: Glasgow coma scale; ABG: Arterial blood gas; GOS: Glasgow outcome score.

Table 4. Parameters of arterial blood gas in expired and discharged patients with severe head trauma

\begin{tabular}{|c|c|c|c|}
\hline \multirow[t]{2}{*}{ Parameter } & \multirow{2}{*}{$\frac{\text { Expired }(n=27)}{\text { Mean } \pm S D}$} & \multirow{2}{*}{$\frac{\text { Discharged }(n=43)}{\text { Mean } \pm \text { SD }}$} & \multirow[t]{2}{*}{$\mathbf{p}$} \\
\hline & & & \\
\hline $\mathrm{pH}$ & $7.30 \pm 0.13$ & $7.24 \pm 0.75$ & 0.68 \\
\hline $\mathrm{PCO}_{2}(\mathrm{mmHg})$ & $35.94 \pm 9.69$ & $33.80 \pm 7.50$ & 0.30 \\
\hline $\mathrm{HCO}_{3}(\mathrm{mEq} / \mathrm{L})$ & $17.88 \pm 4.06$ & $19.24 \pm 4.39$ & 0.19 \\
\hline $\mathrm{PO}_{2}(\mathrm{mmHg})$ & $104.62 \pm 46.06$ & $128.00 \pm 58.33$ & 0.08 \\
\hline $\mathrm{O}_{2} \mathrm{Sat}(\%)$ & $92.88 \pm 7.82$ & $95.75 \pm 5.82$ & 0.08 \\
\hline
\end{tabular}


These findings are in line with similar reports. ${ }^{[8,9]}$

Dumont et al. ${ }^{[5]}$ studied 65 patients with traumatic brain injury in a retrospective manner to determine the effect of prehospital hyperventilation on in-hospital mortality. According to their findings, survival was related to admission $\mathrm{PCO}_{2}$ in patients requiring intubation. The survival rate in patients with normocarbia was significantly better than that in cases with either hypo- or hyper-carbia. In contrast, the mentioned study, there was not a significant association between admission $\mathrm{PCO}_{2}$ and prognosis in our patients. It should be noted that in Dumont's series, ABG was performed within 20 minutes of admission, whereas in the present study ABG assessment was carried out within 4 hours after trauma, when the patients were resuscitated, clinical stability was achieved, and received mechanical ventilation, if necessary.

Pfenninger and Lindner ${ }^{[10]}$ also showed that while the parameters of $A B G$ analysis at the accident site were predictive of the status of patients with head trauma, after intubation and controlled ventilation, the hypercapnia of the comatose patients had been corrected, and a correlation could no longer be found between the levels of GCS score and $\mathrm{PaCO}_{2}$.

The admission $\mathrm{PO}_{2}$ was not significantly correlated with GCS score or GOS in our patients. However, the mean $\mathrm{PO}_{2}$ was higher, although marginally insignificant, in the survived patients comparing with those who expired (128.00 \pm 58.33 $\mathrm{mmHg}$ vs. $104.62 \pm 46.06 \mathrm{mmHg} ; \mathrm{p}=0.08)$. Similar trend was documented for $\mathrm{O}_{2}$ sat $(95.75 \pm 5.82 \%$ vs. $92.88 \pm 7.82 \%$; $p=0.08)$.

Valadka et al. ${ }^{\left[{ }^{\prime \prime}\right]}$ determined thresholds of brain tissue $\mathrm{PO}_{2}$ that are critical for survival after severe head trauma. Based on their findings, the mortality rate increased with increasing duration of time at or below a $\mathrm{PO}_{2}$ of 15 torr or with the occurrence of any $\mathrm{PO}_{2}$ values of $\leq 6$ torr. These findings lay emphasis on the importance of $\mathrm{PO}_{2}$ and $\mathrm{O}_{2}$ Sat in patients with severe head trauma.

Kushi et al. ${ }^{[2]}$ suggested that jugular venous $\mathrm{pH}$ (after the patients stabilized) was useful as an early prognostic indicator in the maintenance of neurological function in patients with traumatic head injury. We were not able to confirm similar role for arterial $\mathrm{pH}$.

In a study by Henzler et al. ${ }^{[6]}$ the parameters of ABG on admission and during hospitalization were compared between head trauma survivors and non-survivors. They showed that $\mathrm{PCO}_{2}$ was similarly elevated in both groups on arrival in the emergency department, reflecting inadequate ventilation.
However, normalization of $\mathrm{PCO}_{2}$ was quicker in survivors than non-survivors. Patients in both groups had a mild metabolic acidosis on admission, which had normalized by $12 \mathrm{~h}$. $\mathrm{PaO}_{2}$ was non-significantly higher in survivors up until 4 hour after the trauma. Overall, the parameters of ABG were not significant predictors of survival in traumatic patients with head injury in this series.

Our findings are in conformity with the results of this study. It seems that changes in the parameters of $A B G$ may reflect a better indicator of prognosis than their values only after admission. Further studies are recommended in this regard.

Based on our findings although $\mathrm{PO}_{2}$ and $\mathrm{O}_{2}$ Sat may be associated with better prognosis in head trauma injury, the parameters of $A B G$ on arrival of patients in the emergency department are not possibly of prognostic value.

Conflict of interest: None declared.

\section{REFERENCES}

1. Winn RH. Youmans neurological surgery. 6th ed. Saunders; 2011. p. 3270-506.

2. Lopez AD, Murray CC. The global burden of disease, 1990-2020. Nat Med 1998;4:1241-3. CrossRef

3. Jennett B, Bond M. Assessment of outcome after severe brain damage. Lancet 1975;1:480-4. CrossRef

4. Werner C, Engelhard K. Pathophysiology of traumatic brain injury. Br J Anaesth 2007;99:4-9. CrossRef

5. Dumont TM, Visioni AJ, Rughani AI, Tranmer BI, Crookes B. Inappropriate prehospital ventilation in severe traumatic brain injury increases in-hospital mortality. J Neurotrauma 2010;27:1233-41. CrossRef

6. Henzler D, Cooper DJ, Mason K. Factors contributing to fatal outcome of traumatic brain injury: a pilot case control study. Crit Care Resusc 2001;3:153-7.

7. Rosenfeld JV, Maas AI, Bragge P, Morganti-Kossmann MC, Manley GT, Gruen RL. Early management of severe traumatic brain injury. Lancet 2012;380:1088-98. CrossRef

8. Helm M, Hauke J, Lampl L. A prospective study of the quality of prehospital emergency ventilation in patients with severe head injury. $\mathrm{Br} \mathrm{J}$ Anaesth 2002;88:345-9. CrossRef

9. Salehpoor F, Bazzazi AM, Estakhri R, Zaheri M, Asghari B. Correlation between catecholamine levels and outcome in patients with severe head trauma. Pak J Biol Sci 2010;13:738-42. CrossRef

10. Pfenninger EG, Lindner KH. Arterial blood gases in patients with acute head injury at the accident site and upon hospital admission. Acta Anaesthesiol Scand 1991;35:148-52. CrossRef

11. Valadka AB, Gopinath SP, Contant CF, Uzura M, Robertson CS. Relationship of brain tissue $\mathrm{PO} 2$ to outcome after severe head injury. Crit Care Med 1998;26:1576-81. CrossRef

12. Kushi H, Moriya T, Saito T, Kinoshita K, Shibuya T, Hayashi N. Importance of metabolic monitoring systems as an early prognostic indicator in severe head injured patients. Acta Neurochir Suppl 1999;75:67-8. 
KLINIK ÇALIŞMA - ÖZET

\section{Ciddi kafa travması olan hastalarda sonlanımla arter kan gazı analizi arasındaki korelasyon}

Dr. Amirmohammad Bazzazi, ${ }^{1}$ Dr. Mohammad Amin Valizade Hasanloei, ${ }^{2}$ Dr. Alireza Mahoori, ${ }^{2}$ Dr. Mahdia Gholamnejad, ${ }^{3}$ Dr. Habibeh Tarverdipour ${ }^{4}$

${ }^{1}$ Urmia Üniversitesi Tıp Bilimleri, Nöroşirürji Anabilim Dalı, Urmia, İran

${ }^{2}$ Urmia Üniversitesi Tıp Bilimleri, Anesteziyoloji Anabilim Dalı, Urmia, İran

3Urmia Üniversitesi Tıp Bilimleri, Göğüs Hastalıkları Anabilim Dalı, Urmia, İran

${ }^{4}$ Urmia Üniversitesi Tıp Bilimleri, Urmia, İran

AMAÇ: Genç kişilerde morbidite ve mortalitenin başlıca nedeni olduğu için travmatik beyin hasarı global halk sağlığının başlıca kaygılarından biridir. Bu çalışmada, arter kan gazı (AKG) parametreleriyle ağır kafa travması geçirmiş hastaların sonlanımı arasındaki olası ilişki araştıııldı.

GEREÇ VE YÖNTEM: Bu ileriye yönelik çalışmada 18 aylık dönem boyunca ağır kafa travmalı 70 hasta Urmia İmam Hümeyni Hastanesi'nde incelendi. Hastaneye kabulden sonraki bir saat içinde AKG parametreleri kaydedildi ve Glasgow koma skalası (GKS) ve Glasgow sonuç skoru (GSS) ile korelasyonları değerlendirildi. Bu parametreler ölen ve taburcu edilen hastalar arasında da karşılaştıııldı.

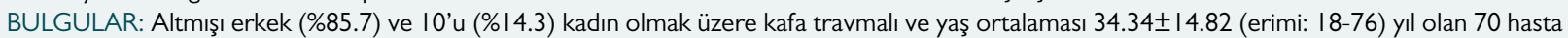
incelendi. Hastanede yatış sırasında ölüm oranı \%38.6 ( $n=27)$ idi. AKG parametreleri, GKS skoru ve GSS skorları arasında anlamlı bir korelasyon yoktu. Ayrıca, ortalama AKG parametreleri açısından sağ kalanlarla hayatını kaybedenler arasında herhangi bir anlamlı farklılık yoktu ( $p>0.05$ ).

TARTIŞMA: Hastaneye kabulde ölçülen AKG ağır kafa travmalı hastalardaki sonlanımın anlamlı bir öngördürücü faktörü değildir.

Anahtar sözcükler: Ağır kafa travması; arter kan gazı; sonlanım.

Ulus Travma Acil Cerrahi Derg 2014;20(4):236-240 doi: 10.5505/tjtes.2014.57089 